\title{
Effects of Lippia sidoides Cham. (Verbenaceae) essential oils on the honey bees Apis mellifera (Apidae: Hymenoptera) foraging
}

\author{
Efecto de aceites esenciales de Lippia sidoides Cham. (Verbenaceae) en las abejas \\ melíferas Apis mellifera (Apidae: Hymenoptera) forrajeras.
}

Izabella M. C. Pinheiro'ㅗ , João Henrique S. Luz ${ }^{2}$, Luis Flávio N. Souza ${ }^{3}$, Ana Cláudia S. S. Oliveira ${ }^{4}$, Eugênio E. Oliveira ${ }^{5}$, Raimundo Wagner S. Aguiar ${ }^{6}$, Gil R. Santos ${ }^{7}$, Talita P. S. Ferreira ${ }^{8}$, Marcela Cristina A. C. Silveira-Tschoeke ${ }^{9}$, Paulo Henrique Tschoeke ${ }^{10}$ \begin{abstract}
ARTICLE DATA
Pregrade student, Departamento de Agronomia, Universidade Federal do Tocantins, ungraduated, Gurupi, Tocantins, Brasil, izabellampinheiro@gmail.com

2 Pregrade student, Departamento de Agronomia, Universidade Federal do Tocantins, ungraduated, Gurupi, Tocantins, Brasil, joaohenri_luz@uft.edu.br

3 Pregrade student, Departamento de Biotecnologia, Universidade Federal do Tocantins, ungraduated, Gurupi, Tocantins, Brasil, luis_flavio@outlook.com

4 Pregrade student, Departamento de Entomologia; Universidade Federal de Viçosa, PhD, Viçosa, 36570 900, Minas Gerais, Brasil, ana.s@ufv.br

5 Professor, Dr. Departamento de Entomologia, Universidade Federal de Viçosa, PhD, Viçosa, Minas Gerais, Brasil eugenio@ufv.br

6 Professor, Dr. Departamento de Biotecnologia, Universidade Federal do Tocantins, PhD, Gurupi, Tocantins, Brasil, rwsa@uft.edu.br

7 Professor, Dr. Departamento de Agronomia, Universidade Federal do Tocantins, PhD, Gurupi, Tocantins, Brasil, gilrsan@uft.edu.br

8 Professor, Dr. Departamento de Biotecnologia, Universidade Federal do Tocantins, PhD, Gurupi, Tocantins, Brasil, cupufer@gmail.com

9 Professor, Dr. Departamento de Agronomia, Universidade Federal do Tocantins, PhD, Gurupi, Tocantins, Brasil, marcelasilveira@uft.edu.br

10 Professor, Dr. Departamento de Agronomia Universidade Federal do Tocantins, PhD, Gurupi, Tocantins, Brasil, pht@uft.edu.br
\end{abstract}

Cite: Pinheiro, I., S. Luz, J., Souza, L., Oliveira, A., Oliveira, E., Aguiar, R., Santos, G., Ferreira, T., Silveira-Tschoeke, M., \& Tschoeke, P. (2019). Effects of Lippia sidoides Cham. (Verbenaceae) essential oils on the honey bees, Apis mellifera (Apidae: Hymenoptera), foraging. Revista De Ciencias Agrícolas. 36(E): 31-41. doi: https://doi. org/10.22267/rcia.1936E.104

Received: July 082019

Accepted: September 272019

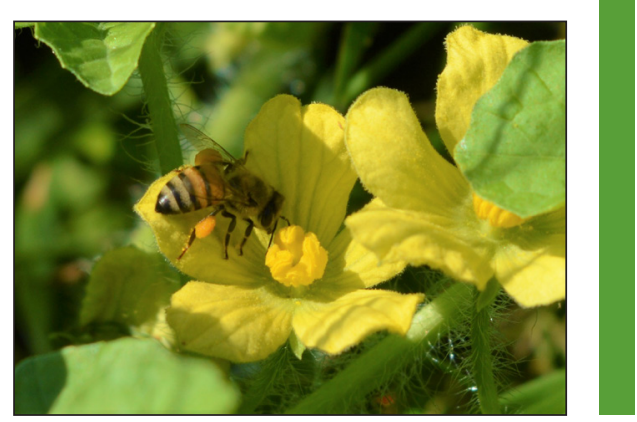

ABSTRACT

The use of plant essential oils has been adopted as less hazardous to the environment and human health than synthetic insecticides used for the control of insects that transmit diseases. Despite of exerting insecticidal activities against several insect disease vectors, the potential impacts on non-target organisms exerted by essential oils extracted from Lippia sidoides (Cham.) have not received adequate attention. Here, we evaluated the susceptibility and potential changes in consumption rates of honey bees, Apis mellifera (L.), when exposed to essential oils extracted from $L$. sidoides. Was exposed forager bees to honey syrup $(50 \% \mathrm{v} / \mathrm{v})$ containing L. sidoides essential oil for $5 \mathrm{~h}$. After this exposure period, the bees received regular honey syrup for another $19 \mathrm{~h}$ period. Six essential oil concentrations was used, namely 1.0, 1.5, $2.0,2.5,3.0$ and $3.5 \mu \mathrm{L}$ of essential oil/mL of syrup, and evaluated the syrup consumption and bees mortality in both periods (at the $5^{\text {th }}$ and $24^{\text {th }} \mathrm{h}$ ). The results reveal that independent of the essential oil concentration, the forager bees fed significantly less on L. sidoides essential oil-containing honey syrup. However, feeding on L. sidoides essential oil-containing honey syrup did not cause significant mortality when compared with bees that were not exposed to the essential oils. Thus, the results demonstrate that L. sidoides essential oils exhibited adequate selectivity against honey bees.

Key words: extracts plant, mortality, pesticides, pollinators.

\section{RESUMEN}

El uso de aceites esenciales de plantas há sido adoptado como menos peligroso para el medio ambiente y la salud humana que los insecticidas sintéticos utilizados para el control de insectos portadores de enfermedades. A pesar de ejercer actividades insecticidas contra varios insectos vectores de enfermedades, los impactos potenciales en los organismos no objetivo ejercidos por los aceites esenciales extraídos de Lippia sidoides (Cham.) no han recibido la atención adecuada. Evaluamos la susceptibilidad y los posibles cambios en las tasas de consumo de las abejas melíferas, Apis mellifera (L.), cuando se exponen a aceites esenciales extraídos de L. sidoides. Se expuso a las abejas recolectoras a jarabe de miel $(50 \% \mathrm{v} / \mathrm{v})$ que contenía aceite esencial de $L$. sidoides durante $5 \mathrm{~h}$. Después de este período de exposición, las abejas recibieron jarabe de miel regular durante otro período de 19 h. Se utilizaron seis concentraciones de aceite essencial: 1.0, 1.5, 2.0, 2.5, 3.0 y $3.5 \mu \mathrm{L}$ de aceite esencial / $\mathrm{mL}$ de jarabe, y se evaluó el consumo de jarabe y la mortalidad de 
las abejas en ambos períodos ( 5 y 24 h). Los resultados revelan que, independientemente de la concentración de aceite esencial, las abejas recolectoras se alimentaron significativamente menos de jarabe de miel que contenía aceite esencial de L. sidoides. Sin embargo, la alimentación con jarabe de miel que contiene aceites esenciales de L. sidoides no causó una mortalidad significativa en comparación con las abejas que no estuvieron expuestas a los aceites esenciales. Por lo tanto, los resultados demuestran que los aceites esenciales de L. sidoides exhibieron una selectividad adecuada contra las abejas melíferas.

Palabras clave: extractos de plantas, mortalidad, pesticidas, polinizadores.

\section{INTRODUCTION}

There is a worldwide trend towards the identification of products of botanical origin with insecticidal activity associated with a lower environmental impact, and essential oils, such as those extracted from Lippia sidoides Cham. (Verbenacea), have been highlighted as an alternative to the pesticides commonly used in the control of the mosquito vector of important diseases (e.g. A. aegypti) (de Lima et al., 2013). However, is necessary to know their effect on non-target insects like pollinators.

According to the World Health Organization, the mosquito Aedes aegypti L. (Diptera: Culicidae) is a vector of viruses related to some of the main neglected tropical diseases in the world, including dengue, zika, and chikungunya (WHO, 2009), but xenobiotics used to effectively control this vector can have negative impacts on the environment. Increased insecticidal efficiency of these products is often associated with increased persistence in the environment ( $\mathrm{Lu}$ et al., 2019), and the residual effect of xenobiotics may negatively affect vertebrate animals (Corcellas et al., 2015; Hughes et al., 2016). Xenobiotics may also have lethal or sublethal effects on non-target insects (Tomé et al., 2012; Ndakidemi et al., 2016; Tomé et al., 2017; Tschoeke et al., 2019) and may result in the development of resistance in populations of insect pests (Smith et al., 2016).

The essential oils of $L$. sidoides contain as major compounds thymol and carvacrol (Melo et al., 2011), which have anti-infective, antiseptic, and anti-inflammatory properties (Botelho et al., 2016), and may be used as insecticides (Figueiredo et al., 2017), acaricides (Camilo et al., 2017), and as fungicides and fungiostatics (Baldim et al., 2019; Ferreira et al., 2018). The larvicidal effect of $L$. sidoides essential oils on A. aegypti was observed at concentrations $\left(\mathrm{LC}_{50}\right)$ ranging from 3.74 to $3.85 \mathrm{mg} / \mathrm{ml}^{-1}$ (Furtado, 2005) and $25.5 \mu \mathrm{g} / \mathrm{ml}^{-1}$ (de Lima et al., 2013). The variations in these results can be related to the different locations of L. sidoides cultivation, plant treatments, and times of collection of the botanical material, all of which can greatly alter the proportions of major compounds present in L. sidoides plants used for the extraction of essential oils.

The application of insecticides commonly used in the control of A. aegypti in urban areas is generally carried out by applying the insecticide to pots of ornamental plants. However, the insecticidal potential of a product also requires the evaluation of its effects on non-target insects such as pollinators or natural enemies (van Lexmond et al., 2015). Bees are non-target insects that can be affected by insecticides, as they can visit the flowers of the treated plants. There are an estimated 20,000 bee species in the world (Wilson-Rich et al., 2018). Of these, the honey bee, Apis mellifera L., has a high economic and environmental importance, since, in addition to the exploitation of hive products (e.g. honey, pollen, wax, propolis, and royal jelly), honey bees are also used worldwide 
in pollinating services for agricultural crops (Tschoeke et al., 2015). Although several previous studies have evaluated the effects of botanical insecticides on target insects, it is also important to evaluate the effects of botanical insecticides on non-target insects, in order to ensure the viability of the use of these insecticides.

Some insecticides such as Spinosad and Azadirachtin, although natural, have been tested on Apis mellifera bees and have been found to have deleterious effects on nontarget organisms (Bailey et al., 2005; Barbosa et al., 2015).

The objective of this study was to verify if the lowest dose of essential oils extracted from L. sidoides described in the literature with insecticidal effect for the control of $A$. aegypti larvae can also have insecticidal effects on adult worker honey bees.

\section{MATERIAL AND METHODS}

Obtaining essential oils from L. sidoides. Fresh leaves of $L$. sidoides were collected in

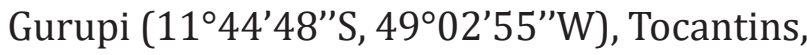
Brazil, according Mourão et al. (2018). The taxonomic identification was confirmed by specialists at the herbarium of the Federal University of São João Del Rei, MG, Brazil, and deposited under reference number 8303. The extraction of essential oils was done using the hydrodistillation process in modified Clevenger apparatus (Aguiar et al., 2015) in the Laboratory of Integrated Pest Management of the Federal University of Tocantins (UFT), at the Gurupi Campus (Mourão et al. 2018). Extracted essential oils were stored at $4^{\circ} \mathrm{C}$ until further analysis.

Gas chromatography-mass spectrometry (GC-MS) analysis. Qualitative analyses were performed through gas chromatography coupled to mass spectrometry (GC-MS) using the Shimadzu GC2010 model equipped with a selective detector for the mass Model QP2010Plus, acoording Mourão et al. (2018). The equipment was operated using a fused silica capillary column RTX-5MS $(30 \mathrm{~m} \times$ $0.25 \mathrm{~mm} \times 0.25 \mu \mathrm{m}$ film thickness), with the following temperature schedule in the column: 60 to $240^{\circ} \mathrm{C}\left(3^{\circ} \mathrm{C} / \mathrm{min}\right)$, temperature of the injector: $220^{\circ} \mathrm{C}$, helium gas carrier, injection with rate of split (1:100) with an injected volume of $1 \mu \mathrm{L}$ of a solution diluted $1: 1000$ in hexane. For the mass spectrometer (MS), an impact energy of $70 \mathrm{~V}$ was used, and the temperature of the source of ions and the interface was set at $200^{\circ} \mathrm{C}$. A homologous series of n-alkanes (C9H20...C26H54) were injected under the same conditions as for samples. The constituents were identified by comparing their mass spectra with those from the databases from the Nist and Wiley 229 libraries, and also by comparing between their rates of retention calculated using those reported in the literature (Adams, 2007). The quantification of the levels of the compounds, expressed as a percentage based on the standardization of areas, was obtained by using a gaseous chromatograph equipped with a detector flame (DIC), using a diagnostic Shimadzu GC-2010, under the following experimental conditions: a capillary column RTX-5MS $(30 \mathrm{~m} \times 0.25 \mathrm{~mm} \times 0.25 \mu \mathrm{m}$ film thickness); temperature of the injector: $220^{\circ} \mathrm{C}$; temperature of the DIC: $300^{\circ} \mathrm{C}$. The column was programmed as follows: initial temperature of $60^{\circ} \mathrm{C}$ with a heating rate of $3^{\circ} \mathrm{C} / \mathrm{min}$ up to $240^{\circ} \mathrm{C}$, then increasing to a heating rate of $10^{\circ} \mathrm{C} / \mathrm{min}$ up to $300^{\circ} \mathrm{C}$ and remaining at this temperature for $10 \mathrm{~min}$; nitrogen drag gas $\left(1.18 \mathrm{~mL} \mathrm{~min}^{-1}\right)$; rate of split: 1:50; pressure in the column: $115 \mathrm{kPa}$, and injected volume: $1 \mu \mathrm{L}$, diluted in hexane $(1: 100 \mathrm{v} / \mathrm{v})$. The calculated retention index was performed according to Mühlen (2009), (Mourão et al. 2018). 
Toxicity bioassays. The tests were performed with adult worker honey bees from four colonies maintained at the UFT experimental apiary and at the Laboratory of Zoology of the Federal University of Tocantins (UFT), Gurupi Campus.

The bees were collected in transparent PET bottles $(500 \mathrm{~mL})$ at the entrance of the beehive. After the bees were taken to the Zoology Laboratory, they were anesthetized with $\mathrm{CO}_{2}$ and then placed in plastic pots $(500 \mathrm{~mL})$ with perforated caps to allow gas exchange. The bees were maintained under controlled conditions which were similar to those of the colony in an incubator BOD (34 \pm $1^{\circ} \mathrm{C}$ and $70 \pm 1 \%$ humidity), and fasted for one hour before the start of each assay.

The experimental design was Completely Randomized, with six treatments plus two controls and five replicates. Each experimental unit consisted of a pot containing 20 bees. During the first five hours of the experiment, the bees received one of the treatments that consisted of syrup (50\% sugar distilled water), supplied in Eppendorf ${ }^{\circledR}$ tubes $(2 \mathrm{~mL})$, mixed with the essential oils extracted from $L$. sidoides, diluted in dimethylsulfoxide (DMSO) at $1.5 \%(\mathrm{v} / \mathrm{v})$. Treatments comprised the following doses of essential oils: 1.0, 1.5, 2.0, $2.5,3.0$, and $3.5 \mu \mathrm{L}$ of essential oil $/ \mathrm{mL}$, as well as a control treatment consisting of only syrup, and a control treatment consisting of DMSO at $1.5 \%(\mathrm{v} / \mathrm{v})$ and syrup. The bees consumed only syrup after five hours of experiment, when the feeder was changed until the end of the experiment, 24 hours after the beginning.

To evaluate how much of the syrup was consumed by the bees, the tubes containing the treatments were weighed before being supplied to the bees. After five hours of feeding the bees with the treatments (syrup + oil), the tubes in each experimental unit were replaced by others containing only sugar water syrup, with known weight. Tubes containing the treatments that were removed from the pots were weighed, and the consumption data was obtained for the first five hours of the experiment. Twenty four hours after initiation of feeding, tubes were weighed again to evaluate syrup consumption from hours 5 to $24 \mathrm{~h}$ of the experiment. Consumption data were divided by the number of live bees and per unit of time (hour). Syrup consumption was measured after the first five hours of bee supply and the result was the difference between the initial and final weight of syrup-containing eppendorf and oil at the doses of each experimental unit. The weight was divided by the number of bees and the amount of hours consumed (5 hours). After five o'clock, another eppendorf containing syrup feathers was supplied to the bees. The consumption of this period (from 5 to 24 hours $=19$ hours) was calculated by the eppendorf weight difference before and after the supply divided by the number of bees in the unit and per hour (19 hours).

Mortality assessments of the different doses of essential oils were performed $5 \mathrm{~h}$ after food exposure, and $24 \mathrm{~h}$ after the start of the experiment.

The data of consumption were analyzed using Generalized Linear Models to adjust the consumption and the ratio of dead bees to essential oil concentrations. The model used considered the difference in consumption between treatments and repetitions. There was no significant difference between repetitions, only between treatments (essential oil concentrations). The Variance Analysis was performed with quasipoisson distribution and testF. The data were analyzed using R Statistical Software (RCoreTeam, 2019). 


\section{RESULTS AND DISCUSSION}

As demonstrated in other investigations (Ferreira et al., 2018), the results revealed that thymol was the main component of oils extracted from $L$. sidoides. The chemical components (expressed as percentage), the retention time of the components, the calculated retention rate are shown in Table 1.

The addition of the essential oils at the different doses to the syrup solution, significantly reduced $(p>0,001)$ feed intake by the bees in the first $5 \mathrm{~h}$ of the experiment (Figure $1 A$ ). After the feeding, from the $5^{\text {th }}$ to the $24^{\text {th }} \mathrm{h}$ of the experiment, only syrup was offered, and during this period, no significant difference was observed $(p=0.05)$ in the consumption per bee per hour (Figure 1B). As demonstrated in Figure 1C, the presence of $L$. sidoides essential oils and solubilizer (DMSO) affected the total consumption $(p>0,001)$.

Table 1. Chemical constituents of $L$. sidoides essential oil and percentage content.

\begin{tabular}{|c|c|c|c|c|}
\hline${ }^{\mathrm{a}} \mathrm{NC}$ & Compounds & ${ }^{\mathrm{b}} \mathrm{RT}$ & ${ }^{\mathrm{c}} \mathrm{CRI}$ & $\%$ \\
\hline 1 & $\alpha$-Thujene & 5.915 & 927 & 0.051 \\
\hline 2 & $\alpha$-Terpinene & 8.680 & 1018 & 0.091 \\
\hline 3 & $\rho$-Cymene & 8.944 & 1025 & 1.162 \\
\hline 4 & $\gamma$-Terpinene & 10.176 & 1058 & 0.250 \\
\hline 5 & cis-Sabinene hydrate & 10.656 & 1071 & 0.102 \\
\hline 6 & 4-Terpineol & 15.19 & 1182 & 0.453 \\
\hline 7 & Thymol methyl ether & 17.264 & 1230 & 0.430 \\
\hline 8 & Thymol & 20.075 & 1294 & 92.684 \\
\hline 9 & (E)-caryophyllene & 25.369 & 1419 & 2.235 \\
\hline 10 & $\alpha$-Humulene & 26.849 & 1456 & 0.134 \\
\hline 11 & Caryophyllene oxide & 31.878 & 1582 & 0.617 \\
\hline \multicolumn{2}{|c|}{ Total } & & \multicolumn{2}{|c|}{98.179} \\
\hline
\end{tabular}

${ }^{a} \mathrm{NC}$ : Number of compounds; bRT: retention time; cCRT: calculated retention index. 


\section{A oil-containing syrup consumption}

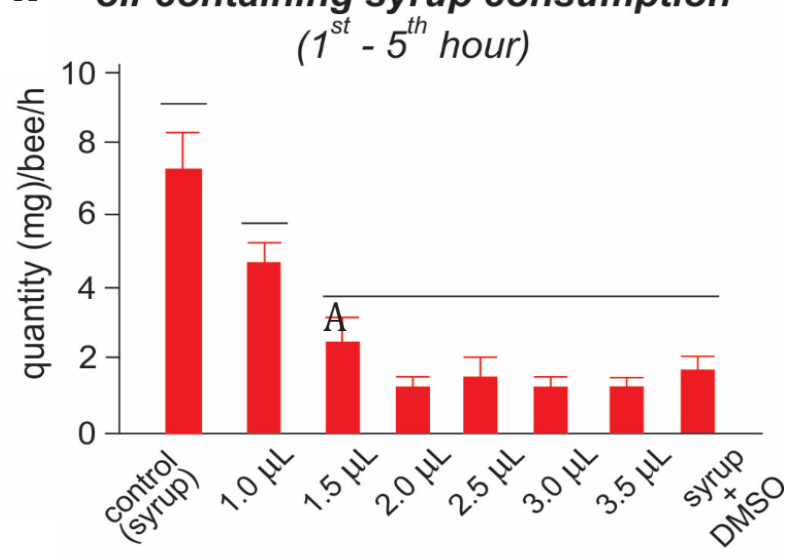

B

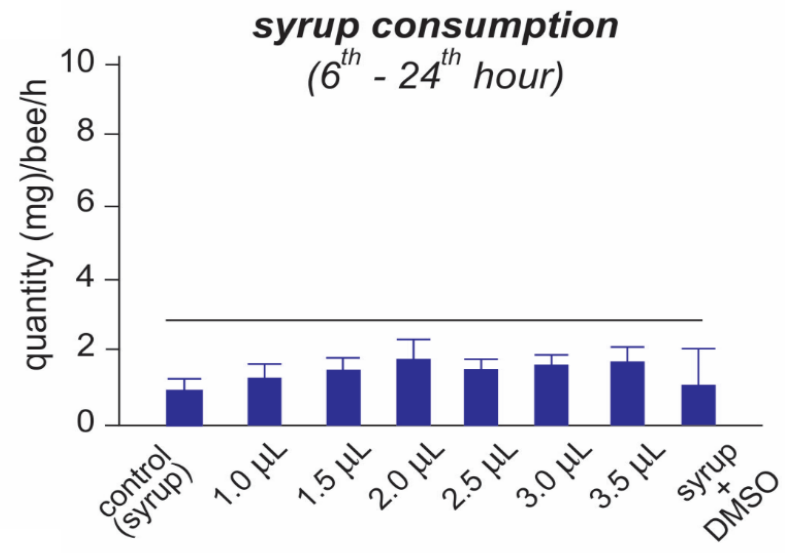

C

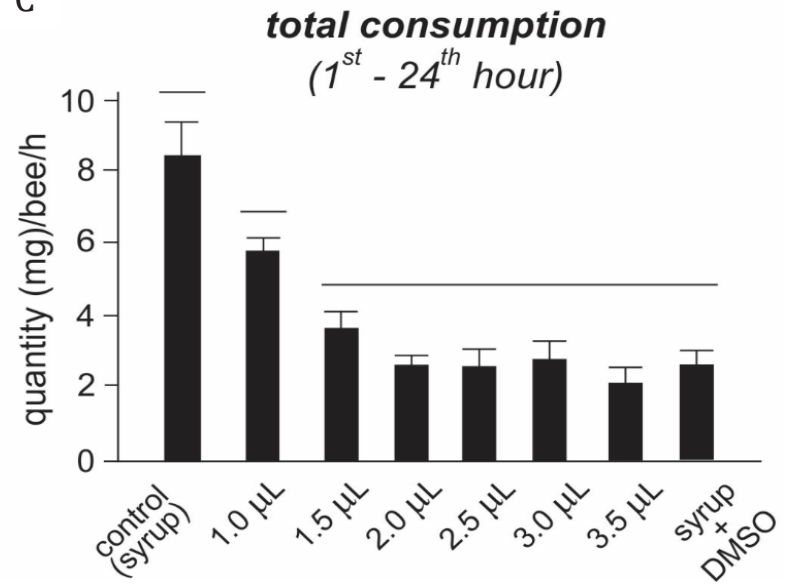

Figure 1. A Consumption of syrup mixed with Lippia sidoides essential oils at different concentrations during the exposure time (i.e., from $1^{\text {st }}$ to $5^{\text {th }}$ hour). B Syrup consumption, from the $6^{\text {th }}$ to $24^{\text {th }} \mathrm{h}$ after the start of the experiment. $\boldsymbol{C}$ Total consumption of syrup during the $24 \mathrm{~h}$ period.
It is worth to note that the syrup solution containing essential oil did also contain DMSO (at $1.5 \%(\mathrm{v} / \mathrm{v})$ ). The lines in the graphs indicate significant differences between the results.

Despite the results had revealed a significant reduction in the consumption of the mixture (syrup + L. sidoides essential oils) by the bees, there was no significant difference in bees mortality among the essential oil doses tested at the two exposure intervals (Figure $2 A$ and $2 B$ ). There was also no statistical difference in relation to the total number of bee deaths in $24 \mathrm{~h}$ (Figure 2C).

The bees used in this study received the necessary amount of sugars to stay alive during the experiment. The consumption of syrup by bees in the control treatment was approximately 8mg of syrup per day, and a reduction in syrup consumption occurred when the syrup contained $L$. sidoides essential oils. An adult worker bee requires approximately $4 \mathrm{mg}$ of usable sugars per day to survive (Barker and Lehner, 1974), and when it is in field work, its caloric reserves are enough for a flight of 15 to 60 minutes. The concentration of glucose and trehalose (energy reserve) declines by 50\% after 30 minutes without feeding, and this can be restored in 10 minutes after feeding (Brodschneider and Crailsheim, 2010). Caged bees fed exclusively on carbohydrates survived better when fed sucrose (LT $50=56.3$ days) compared to honey (31.3 days) or high fructose corn syrup (37.7 days) (Barker and Lehner, 1974; Brodschneider and Crailsheim, 2010). 
A

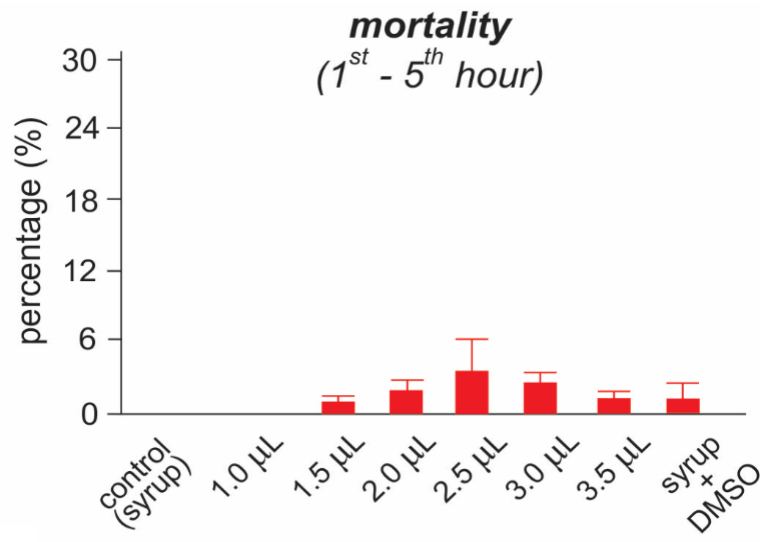

B

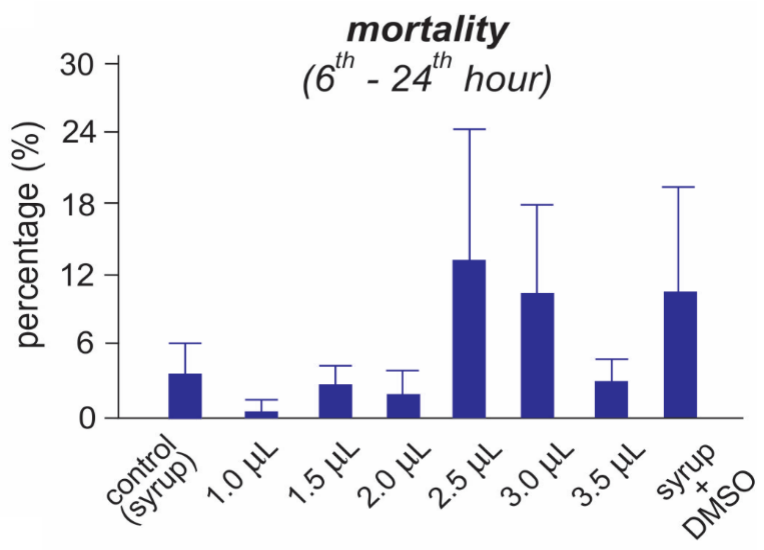

C

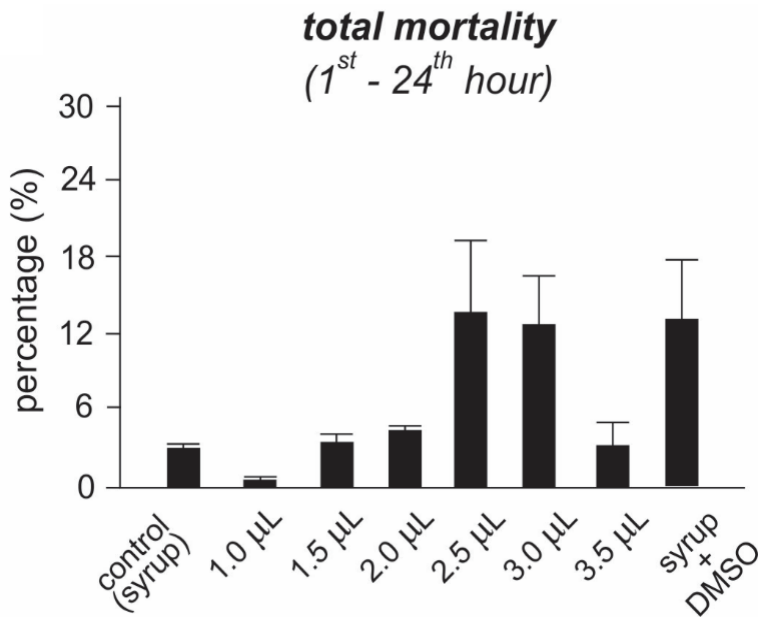

Figure 2. $\boldsymbol{A}$ Percentage (\%) of dead bees after the $5 \mathrm{~h}$ of exposure to honey syrup containing the Lippia sidoides essential oil. $\boldsymbol{B}$ Percentage of dead bees recorded from the $6^{\text {th }}$ to $24^{\text {th }} \mathrm{h}$ after the start of the experiment. $\boldsymbol{C}$ Total mortality during the 24 $\mathrm{h}$ period. It is worth to note that the syrup solution containing essential oil did also contain DMSO at $1.5 \%(\mathrm{v} / \mathrm{v})$. There was no significant difference between treatments in any of the periods.
Oral toxicity tests in laboratory studies on the effect of pesticides on bees have already established appropriate methodologies. In these tests, the bees have free access to the food, and a uniform distribution of food between all bees is assumed, either by direct contact or trophallaxis (Crailsheim, 1998). The results of the experiments are more reliable when more bees are included in treatment groups (more than 10 bees per cage) and receive feeding for a longer period of time (up to $48 \mathrm{~h}$ ) (Brodschneider et al., 2017). Caged bees consume harmful solutions if there are no other options for food consumption (Desmedt et al., 2016), and, in larger groups the distribution of food available to the bees is more uniform. These results explain why during a short period of treatment supply (5h), bees avoided consuming food with oil.

A reduction in syrup consumption was observed with increasing doses of L. sidoides essential oils, which demonstrates a deterrent effect on the bees. However, $L$. sidoides essential oils were not toxic to the bees in the first $24 \mathrm{~h}$ of exposure, since the bees' mortality rates did not differ between treatments. Another study conducted using the same oil, but for control of Varroa sp. (Acari: Varroidae) mites showed similar results, and no toxicity to bees was reported (Moreira et al., 2016). However, in the study by Moreira et al. (2016), the bees were exposed to a $1 \mathrm{~cm}^{2}$ sponge soaked with the essential oil at doses of 100 and $200 \mu \mathrm{L}$, but the oil was not offered for consumption by the bees. 
Although the mechanism of thymol act on bees is not fully undesrtood yet, it has been demonstrated that thymol have toxic effects on various organisms through the inhibition of acetylcholinesterase (AChE) (Jukic et al., 2007). The enzyme AChE is responsible for hydrolyzing the neurotransmitter acetylcholine (ACh) in cholinergic synapses, and this affects the transmission of nerve impulses from the nervous system of insects, which is responsible for vital functions including skeletal muscle tone, intestinal peristalsis, and secretion. If AChE is inhibited, ACh in insects would be constantly active, resulting in nervous hyperactivity, tetany, and death. Thus, the potential effects of $L$. sidoides essential oil on AChE of $A$. Mellifera still need to be provided.

Even though essentials oils extracted from L. sidoides were not found to have an acute lethal effect on bees, there may be sublethal effects on reproduction over time. The defense of insects against xenobiotics includes enzymatic detoxification by cytochrome monooxygenases, or by esterases and several transferases, which are normally present in the intestine and adipose tissue of insects, contributing to the degradation of contaminants that penetrate the cuticle (Zaworra and Nauen, 2019). This detoxification process requires energy and resources normally used in basic physiological processes, resulting in lower reproductive fitness (Rand et al., 2015: Gashout et al., 2018). Studies on sublethal effects of pesticides on natural enemies are important because target species and their natural enemies are exposed to sub-lethal concentrations for a period longer than they are exposed to lethal concentrations as a result of insecticide residues in the field.

Most studies on the effects of insecticides on bees are concentrated on adult workers, which were also used in this study. However, all stages of development and castes of bees can potentially be affected by insecticide residues (Tomé et al., 2012) and there is also the possibility of the pesticide leaving residues in bee products, as has been demonstrated, for example, in the case of thymol (Serra Bonvehí et al., 2016).

\section{CONCLUSIONS}

Bees selected against consumption of the essential oils extracted from $L$. sidoides, and that these oils did not cause acute toxicity in honey bees at the doses tested. However, there is a possibility of contamination, and pesticides can have sublethal effects. As such, it is recommended that, before using L. sidoides essential oils as a botanical insecticide, further studies should be conducted to build upon these results. Such studies should evaluate the effects of $L$. sidoides essential oils on immature stages of honey bees, and on the reproductive performance of honey bee colonies.

Conflict of interest: The authors declare that there is no conflict of interest.

\section{BIBLIOGRAPHIC REFERENCES}

Adams, R.P. (2007). Identification of essential oil components by gas chromatography/mass spectrometry. Carol Stream: Allured Publishing Corporation. 804p.

Aguiar, R.W.S., Dos Santos, S.F., Da Silva Morgado, F., Ascencio, S.D., De Mendonça Lopes, M., Viana, K.F., Didonet, J. \& Ribeiro, B.M. (2015). Insecticidal and Repellent Activity of Siparuna guianensis Aubl. (Negramina) against Aedes aegypti and Culex quinquefasciatus. PLOS ONE. 10 (2): e0116765. doi:_https://doi. org/10.1371/journal.pone.0116765 
Bailey, J., Scott-Dupree, C., Harris, R., Tolman, J.\& Harris, B., (2005). Contact and oral toxicity to honey bees (Apis mellifera) of agents registered for use for sweet corn insect control in Ontario, Canada. Apidologie. 36 (4): 623-633. doi: https://doi.org/10.1051/apido:2005048

Baldim, I., Tonani, L., Von Zeska Kress, M.R. \& Pereira Oliveira, W., (2019). Lippia sidoides essential oil encapsulated in lipid nanosystem as an anti-Candida agent. Industrial Crops and Products. 127: 73-81. doi: https://doi. org/10.1016/j.indcrop.2018.10.064

Barbosa, W.F., De Meyer, L., Guedes, R.N.C. \& Smagghe, G. (2015). Lethal and sublethal effects of azadirachtin on the bumblebee Bombus terrestris (Hymenoptera: Apidae). Ecotoxicology. 24 (1): 130-142. doi: htpps:// doi.org/10.1007/s10646-014-1365-9

Barker, R.J. \& Lehner, Y. (1974). Acceptance and sustenance value of naturally occurring sugars fed to newly emerged adult workers of honey bees (Apis mellifera L.). J. Exp. Zoo. 187 (2): 277. doi: https://doi.org/10.1002/ jez.1401870211

Botelho, M.A., Barros, G., Queiroz, D.B., Carvalho, C.F., Gouvea, J., Patrus, L., Bannet, M., Patrus, D., Rego, A., Silva, I., Campus, G. \& Araújo-Filho, I. (2016). Nanotechnology in Phytotherapy: Antiinflammatory Effect of a Nanostructured Thymol Gel from Lippia sidoides in Acute Periodontitis in Rats. Phytother. Res. 30 (1): 152-159. doi: https://doi.org/10.1002/ ptr.5516

Brodschneider, R.\& Crailsheim, K. (2010). Nutrition and health in honey bees. Apidologie. 41 (3): 278-294. doi:https://doi.org/10.1051/ apido/2010012

Brodschneider, R., Libor, A., Kupelwieser, V. \& Crailsheim, K. (2017). Food consumption and food exchange of caged honey bees using a radioactive labelled sugar solution. PLOS ONE. 12(3): e0174684. doi:_https://doi. org/10.1371/journal.pone.0174684

Camilo, C.J., Alves Nonato, C.D.F., GalvãoRodrigues, F.F., Costa, W.D., Clemente, G.G., Sobreira Macedo, M.A.C., Galvão Rodrigues, F.F. \& Da Costa, J.G.M. (2017). Acaricidal activity of essential oils: a review. Trends in Phytochemical Research. 1(4): 183-198. doi: http://tpriaushahrood.ac.ir/article_535451.html

Corcellas, C., Eljarrat, E. \& Barceló, D. (2015). First report of pyrethroid bioaccumulation in wild river fish: A case study in Iberian river basins (Spain). Environ. Int. 75: 110-116. doi:.https:// doi.org/10.1016/j.envint.2014.11.007

Crailsheim, K. (1998). Trophallactic interactions in the adult honeybee (Apis mellifera L.). Apidologie. 29 (1-2): 97-112. doi: https://doi. org/10.1051/apido:19980106

De Lima, G.P.G., De Souza, T.M., De Paula Freire, G., Farias, D.F., Cunha, A.P., Ricardo, N.M.P.S., De Morais, S.M. \& Carvalho, A.F.U. (2013). Further insecticidal activities of essential oils from Lippia sidoides and Croton species against Aedes aegypti L. Parasitol. Res. 112 (5): 19531958. doi: https://doi.org/10.1007/s00436013-3351-1

Desmedt, L., Hotier, L., Giurfa, M., Velarde, R. \& De Brito Sanchez, M.G. (2016). Absence of food alternatives promotes risk-prone feeding of unpalatable substances in honey bees. Sci. Rep. 6 : 31809. doi: https://doi.org/10.1038/ srep31809

Ferreira, T.P.S., Mourão, D.S.C., Dos Santos, G.R., Guimarães, L.G.L., Pires, E.C.F., Santos, W.F. \& Aguiar, R.W.S., (2018). Fungistatic activity of essential oil of Lippia sidoides Cham. against Curvularia lunata Afri. J. Agri. Res. 13 (14): 704-713. doi: https://doi.org/10.5897/ AJAR2018.12977

Figueiredo, M.B., Gomes, G.A., Santangelo, J.M., Pontes, E.G., Azambuja, P., Garcia, E.S. \& Carvalho, M.G.D. (2017). Lethal and sublethal effects of essential oil of Lippia sidoides (Verbenaceae) and monoterpenes on Chagas disease vector Rhodnius prolixus. Memórias do Instituto Oswaldo Cruz. 112: 63-69. doi: http:// dx.doi.org/10.1590/0074-02760160388

Furtado, R.F. (2005). Atividade larvicida de oleos essenciais contra Aedes aegypti L. (Diptera: Culicidae). Neotrop. Entomol. 34 (5): 843848. doi: http://dx.doi.org/10.1590/S1519566X2005000500018 
Pinheiro et al. - Foraging Apis mellifera with essential oil solutions.

Gashout, H.A., Goodwin, P.H. \& Guzman-Novoa, E., (2018). Lethality of synthetic and natural acaricides to worker honey bees (Apis mellifera) and their impact on the expression of health and detoxification-related genes. Environ. Sci. Pollut. R. 25 (34): 34730-34739. doi: http://dx.doi.org/10.1007/s11356-0183205-6

Hughes, M.F., Ross, D.G., Starr, J.M., Scollon, E.J., Wolansky, M.J., Crofton, K.M. \& DeVito, M.J. (2016). Environmentally relevant pyrethroid mixtures: A study on the correlation of blood and brain concentrations of a mixture of pyrethroid insecticides to motor activity in the rat. Toxicology. 359-360: 19-28. doi: https:// doi.org/10.1016/j.tox.2016.06.013

Jukic, M., Politeo, O., Maksimovic, M., Milos, M. \& Milos, M., (2007). In Vitro acetylcholinesterase inhibitory properties of thymol, carvacrol and their derivatives thymoquinone and thymohydroquinone. Phytother. Res. 21 (3): 259-261._doi:__https://doi.org/10.1002/ ptr.2063

Lu, Q., Sun, Y., Ares, I., Anadón, A., Martínez, M., Martínez-Larrañaga, M.R., Yuan, Z., Wang, X. \& Martínez, M.A. (2019). Deltamethrin toxicity: A review of oxidative stress and metabolism. Environ. Res. 170: 260-281. doi: https://doi. org/10.1016/j.envres.2018.12.045

Melo, M.T.P., Carvalho Júnior, W.G.O., Souza, M.F., Figueiredo,L.S.\& Martins, E.R.(2011).Produção de fitomassa e teor de óleo essencial de folhas de alecrim-pimenta (Lippia sidoides Cham.) em diferentes espaçamentos de plantio. Rev. Bras. Pl. Med. 13: 230-234. doi: http://dx.doi. org/10.1590/S1516-05722011000200016.

Moreira, S.B.L.C., Guimarães-Brasil, M.O., HolandaNeto, J.P., Souza, M.C.M. \& Souza, E.A. (2016). Avaliação in vitro da eficácia do óleo essencial do alecrim pimenta (Lippia sidoides) no combate a varroase em Apis mellifera L. Revista Verde de Agroecologia e Desenvolvimento Sustentável. 11 (1). doi:_https://doi.org/10.18378/rvads. v11i1.4002

Mühlen, C.V. (2009). Índices de retenção em cromatografia gasosa bidimensional abrangente. Sci. Chromatogr. 1: 21-29.
Mourão, D.S.C.; Souza, M.R.; Santos, G.R.; Guimarães, L.G.L.; Pires, E.C.F.; Santos, W.F.; Aguiar, R.W.S. (2018) Fungistatic activity of essential oils of Lippia sidoides Cham. Against Curvularia lunata. African Journal of Agricultural Research. 13(14) 704:713. doi: http://dx.doi.org/10.5897/AJAR.2018.12977

Ndakidemi, B., Mtei, K. \& Ndakidemi, P.A., (2016). Impacts of synthetic and botanical pesticides on beneficial insects. Agri. Sci. 7 (6): 364-372. doi: http://dx.doi.org/10.4236/as.2016.76038

Rand, E.E.D., Smit, S., Beukes, M., Apostolides, Z., Pirk, C.W.W. \& Nicolson, S.W. (2015). Detoxification mechanisms of honey bees (Apis mellifera) resulting in tolerance of dietary nicotine. Sci. Rep. 5: 11779._doi: http:// dx.doi.org/10.1038/srep11779

RCoreTeam. (2019). R: A Language and Environment for Statistical Computing. Package GLM, NLME. Vienna, Austria: R Foundation for Statistical Computing.

Serra Bonvehí, J., Ventura Coll, F. \& Ruiz Martínez, J.A. (2016). Residues of essential oils in honey after treatments to control Varroa destructor. J. Essent. Oil Res. 28 (1): 22-28. doi: http:// dx.doi.org/10.1080/10412905.2015.1076741

Smith, L.B., Kasai, S. \& Scott, J.G., (2016). Pyrethroid resistance in Aedes aegypti and Aedes albopictus: Important mosquito vectors of human diseases. Pest. Biochem. Physiol. 133: 1-12. doi: https://doi.org/10.1016/j. pestbp.2016.03.005

Tomé, H.V.V., Martins, G.F., Lima, M.A.P., Campos, L.A.O. \& Guedes, R.N.C. (2012). ImidaclopridInduced Impairment of Mushroom Bodies and Behavior of the Native Stingless Bee Melipona quadrifasciata anthidioides. PLOS ONE. 7 (6): e38406. doi: http://dx.doi.org/10.1371/ journal.pone.0038406

Tomé, H.V.V., Ramos, G.S., Araújo, M.F., Santana, W.C., Santos, G.R., Guedes, R.N.C., Maciel, C.D., Newland, P.L. \& Oliveira, E.E. (2017). Agrochemical synergism imposes higher risk to Neotropical bees than to honeybees. Royal Soc.Open Sci. 4: 160866. doi: https://doi. org/10.1098/rsos.160866 
Tschoeke, P.H., Oliveira, E.E., Dalcin, M.S., SilveiraTschoeke, M.C.A.C. \& Santos, G.R. (2015). Diversity and flower-visiting rates of bee species as potential pollinators of melon (Cucumis melo L.) in the Brazilian Cerrado. Sci. Hortic. 186: 207-216. doi: https://doi. org/10.1016/j.scienta.2015.02.027

Tschoeke, P.H., Oliveira, E.E., Dalcin, M.S., SilveiraTschoeke, M.C.A.C., Sarmento, R.A. \& Santos, G.R. (2019). Botanical and synthetic pesticides alter the flower visitation rates of pollinator bees in Neotropical melon fields. Env. Pollution. 251: 591-599. doi: https://doi.org/10.1016/j. envpol.2019.04.133

Van Lexmond, M.B., Bonmatin, J.M., Goulson, D. \& Noome, D.A. (2015). Worldwide integrated assessment on systemic pesticides. Environ. Sci. Pollut. Res. 22 (1): 1-4. doi: http://dx.doi. org/10.1007/s11356-014-3220-1

World Health Organization. (2009). Dengue: guidelines for diagnosis, treatment, prevention and control. Geneva: World Health Organization. $147 \mathrm{p}$.

Wilson-Rich, N., Allin, K., Carreck, N. \& Quigley, A. (2018). The Bee: a natural history. New Jersey,: Princeton University Press. 224p.

Zaworra, M. \& Nauen, R. (2019). New approaches to old problems: Removal of phospholipase A2 results in highly active microsomal membranes from the honey bee, Apis mellifera. Pest. Biochem. Physiol. doi: https:// doi.org/10.1016/j.pestbp.2019.04.014 